\title{
Chemical sensing of plant stress at the ecosystem scale
}

\author{
T. Karl, A. Guenther, A. Turnipseed, E. G. Patton, and K. Jardine \\ National Center for Atmospheric Research, 1850 Table Mesa Dr, Boulder, 80301, CO, USA \\ Received: 24 April 2008 - Published in Biogeosciences Discuss.: 6 June 2008 \\ Revised: 4 August 2008 - Accepted: 12 August 2008 - Published: 8 September 2008
}

\begin{abstract}
Significant ecosystem-scale emissions of methylsalicylate (MeSA), a semivolatile plant hormone thought to act as the mobile signal for systemic acquired resistance (SAR), were observed in an agroforest. Our measurements show that plant internal defence mechanisms can be activated in response to temperature stress and are modulated by water availability on large scales. Highest MeSA fluxes (up to $0.25 \mathrm{mg} / \mathrm{m}^{2} / \mathrm{h}$ ) were observed after plants experienced ambient night-time temperatures of $\sim 7.5^{\circ} \mathrm{C}$ followed by a large daytime temperature increase (e.g. up to $22^{\circ} \mathrm{C}$ ). Under these conditions estimated night-time leaf temperatures were as low as $\sim 4.6^{\circ} \mathrm{C}$, likely inducing a response to prevent chilling injury. Our observations imply that plant hormones can be a significant component of ecosystem scale volatile organic compound (VOC) fluxes (e.g. as high as the total monoterpene (MT) flux) and therefore contribute to the missing VOC budget. If generalized to other ecosystems and different types of stresses these findings suggest that semivolatile plant hormones have been overlooked by investigations of the impact of biogenic VOCs on aerosol formation events in forested regions. Our observations show that the presence of MeSA in canopy air serves as an early chemical warning signal indicating ecosystem-scale stresses before visible damage becomes apparent. As a chemical metric, ecosystem emission measurements of MeSA in ambient air could therefore support field studies investigating factors that adversely affect plant growth.
\end{abstract}

\section{Introduction}

Volatile organic compounds (VOCs) critically influence the composition of the Earth's atmosphere by fueling

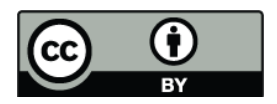

Correspondence to: T. Karl

(tomkarl@ucar.edu) tropospheric chemistry (Atkinson, 2000), thereby modulating its oxidation capacity and providing condensable material for organic aerosol formation (Kanakidou et al., 2005). On a global scale the emission strength of biogenic VOCs $(\sim 1000 \pm 600 \mathrm{Tg} / \mathrm{y})$ dominates the annual VOC budget, accounting for up to $90 \%$ of the reduced carbon flux entering the atmosphere (Guenther et al., 1995). In recent years indirect evidence was presented suggesting that substantial amounts of unknown VOCs are emitted from terrestrial plants (di Carlo et al., 2004; Goldstein and Galbally, 2007), which are currently not included in comprehensive biogenic emission inventories (Kesselmeier and Staudt, 1999). Whether these biogenic VOC emissions are large enough to influence atmospheric chemistry in profound ways depends on the magnitude of their ecosystem scale fluxes as well as their physiochemical properties.

Here we report significant ecosystem-scale fluxes of the plant hormone MeSA above a walnut (Paradox Hybrid; Juglans californica $\times$ Juglans regia) agroforest. MeSA is a biologically active compound thought to be one of the key airborne messenger molecules synthesized by plants in response to stress (e.g. Shulaev et al., 1997, Baldwin et al., 2006). MeSA has been shown to act as a mobile signal for systemic acquired resistance (SAR) by being converted to salicylic acid (SA) in plants (Park et al., 2006). SA is known to promote the expression of defense related genes in response to herbivores and pathogens (Li et al., 2002). While two major biochemical routes for immune responses (jasmonic acid and salicylic acid pathway) exist (e.g. Beckers and Speol, 2006), the methyl ester of SA (MeSA) presents the less soluble and more volatile form making it a suitable candidate for plant to plant communication through the air (rather than the phloem alone). In the past, laboratory experiments exposing plants to mixing ratios exceeding $60 \mathrm{ppbv}$ (and ranging up to $40 \mathrm{ppmv}$ ) were used to study the ecological role of MeSA (Shulaev et al., 1999; Peñuelas et al., 2006). Because real ecosystems are challenged by a number

Published by Copernicus Publications on behalf of the European Geosciences Union. 

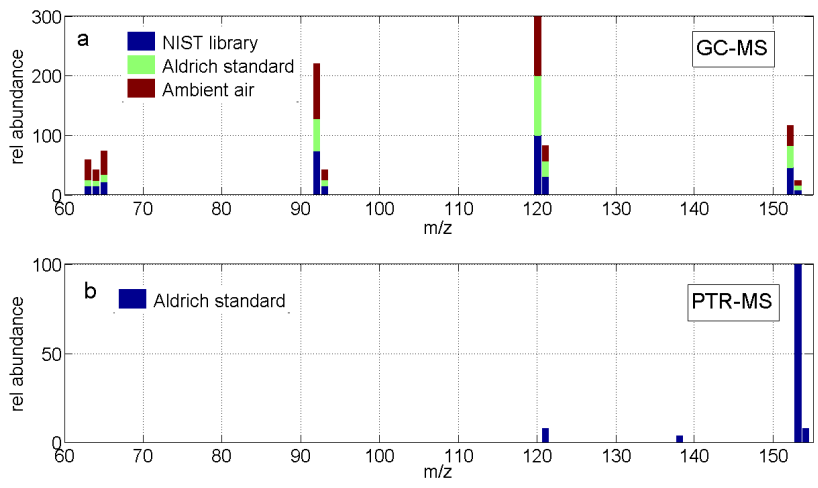

Fig. 1. (a) Stacked bar plot of electron-impact ionization mass spectra of methyl salicylate (NIST library, an authentic standard (SigmaUltra, Sigma Aldrich, CAS 119-36-8, Milwaukee, WI, USA) and ambient air measurements). (b) Proton-transfer-reaction mass spectra of methyl salicylate using an authentic standard (SigmaUltra, Sigma Aldrich, CAS 119-36-8, Milwaukee, WI, USA).

of stresses that cannot realistically be reproduced in the laboratory, it is currently only assumed that the biochemical machinery that produces biologically active volatiles in laboratory experiments operates in similar ways in the real world. One of the big uncertainties to date in understanding the ecological importance of MeSA is the fact that typical emission rates and concentrations in the real canopy atmosphere in response to naturally occurring stresses are not known (Baldwin et al., 2006; Peñuelas et al., 2006). Here we report - to our knowledge - the first measurements of MeSA in ambient air and quantify ecosystem scale emissions in an agroforest.

\section{Methods}

\subsection{The Canopy Horizontal Array Turbulence Study (CHATS) field site}

The Canopy Horizontal Array Turbulence Study (CHATS) took place from March through June, 2007, and is the third in the series of Horizontal Array Turbulence Study (HATS) experiments. The HATS experiments have been instrumental in testing and developing sub-filter-scale models for largeeddy simulations of planetary boundary layer turbulence. The CHATS campaign took place in a deciduous walnut orchard (Paradox Hybrid; Juglans californica $\times$ Juglans regia; $\sim 11 \mathrm{~m}$ canopy height) near Dixon, California (N $38^{\circ}$ $29^{\prime} 15^{\prime \prime}$, W $121^{\circ} 50^{\prime} 45^{\prime \prime}$ ). CHATS included a thirty-meter tower instrumented with assorted turbulence instrumentation, fast and slow chemistry measurements, aerosol samplers, and radiation instrumentation. In particular data obtained from 13 sonic anemometers (mounted at 1.5, 3, 4.5, 6, 7.5, 9, 10, 11, 12.5, 14, 18, 23 and 29 m ) (CSAT3, Campbell, UK) are used to calculate in-canopy dispersion; 12 hygrothermometers (TRH, NCAR,USA) (mounted at 1.5, 3, 4.5,
$6,7.5,9,10,11,14,18,23,29 \mathrm{~m})$ provided information on the vertical temperature and humidity structure. Soil temperature (Model REBS, Micromet Systems, UK) and moisture (Model Ech2o, Decagon, USA) were measured at $5 \mathrm{~cm}$ soil depth. Four pyranometers (Model CM21, Kipp \& Zonen, Netherlands; Model PSP, Eppley, USA; Model CG4, Kipp \& Zonen, Nederlands; Model PIR, Eppley, USA) were deployed at 2 and $16 \mathrm{~m}$. Plant area index was measured using a LICOR-2000 (Model LAI-2000, LICOR, USA). A complete list of details for CHATS can be found at http: //www.eol.ucar.edu/rtf/projects/CHATS/isff/.

\subsection{Identification of MeSA using GC-MS}

A field deployed Gas Chromatograph with Mass Spectrometer (GC-MS; HAPSITE Smart, INFICON, USA) was used for in-situ identification of MeSA in ambient air within and above the walnut agroforest and in emission samples from walnut leaves. The GC-MS used a $30 \mathrm{~m} \times 0.32 \mathrm{~mm}$ ID, $1 \mu \mathrm{m}$ SPB- 1 column, temperature programmed with an initial hold of $2 \mathrm{~min}$ at $50^{\circ} \mathrm{C}$ followed by an increase to $80^{\circ} \mathrm{C}$ at $15^{\circ} \mathrm{C} \mathrm{min}{ }^{-1}$ followed by an increase to $110^{\circ} \mathrm{C}$ at $3^{\circ} \mathrm{C} \mathrm{min}^{-1}$ and then to $200^{\circ} \mathrm{C}$ at $9^{\circ} \mathrm{C} \mathrm{min}^{-1}$. The limit of detection (LOD) for MeSA and MT was determined as 10 pptv respectively. Identification was confirmed by comparison of mass spectra in the NIST (National Institute of Standards and Technology, USA) database and an authentic standard (SigmaUltra, Sigma Aldrich, CAS 119-36-8, Milwaukee, WI, USA), shown in Fig. 1a, and by comparison of retention index with the authentic standard. Samples $(\sim 2 \mathrm{~L})$ were preconcentrated on an internal Tenax adsorbent concentrator (INFICON, NY, USA). An assessment of artefacts demonstrated that MeSA blank levels were negligible. No other compounds exhibiting a nominal molecular weight of MeSA (152 amu) were detected on GC-MS mass scans.

\subsection{Proton-Transfer-Reaction Mass Spectrometer (PTR- MS)}

A high sensitivity Proton-Transfer-Reaction Mass Spectrometer was used for gradient measurements of selected VOCs. The instrument is based on soft chemical ionization using protonated water ions $\left(\mathrm{H}_{3} \mathrm{O}^{+}\right)$. It combines the advantage of online analysis while maintaining linearity and low detection limits (Ionicon, Austria) (Hansel et al., 1999). The detection limit for methyl salicylate and total monoterpenes for a $5 \mathrm{~s}$ integration time was 2 and $5 \mathrm{pptv}$ respectively. The instrument was operated at $2.3 \mathrm{mbar}$ drift pressure and $540 \mathrm{~V}$ drift voltage and calibrated using two multicomponent ppmv VOC standards: VOC standard 1 contained a mixture of methanol, acetonitrile, acetaldehyde, acetone, isoprene, methyl vinyl ketone, methyl ethyl ketone, benzene, toluene, m,o,p xylenes and camphene; VOC standard 2 containted a mixture of benzene, toluene, m,o,p xylenes + ethylbenzene, chlorobenzene, trimethylbenzenes, dichlorobenzenes 
and trichlorobenzenes. Ultrapure methyl salicylate (SigmaUltra, Sigma Aldrich, CAS 119-36-8, Milwaukee, WI, USA) was injected into the instrument to determine the instrument specific response for this compound (Fig. 1b). The instrument sequentially sampled of six independent $\frac{1}{4}$ " inch Teflon (PFA) sampling lines mounted at 1.5, 4.5, 9, 11, 14 and $23 \mathrm{~m}$ on a $30 \mathrm{~m}$ tall Rohn Tower. A valve switching system changed sampling lines every $5 \mathrm{~min}$. Gradients were calculated from the $5 \mathrm{~min}$ averages. High flow rates through the sampling lines resulted in delay times of less than 8-12 seconds, measured by spiking a VOC pulse at each sampling inlet.

\subsection{Ozone measurements}

Ozone concentrations were also measured via the 6-level sampling manifold by UV absorbance (2B Technologies, Model 205). Ozone concentrations were measured every $10 \mathrm{~s}$ and then averaged over the entire 5 min sampling time on each level, excluding only the first $15 \mathrm{~s}$ to insure adequate flushing of the connecting gas lines. The ozone analyzer was compared with laboratory instruments both prior to and following the experiment and found to agree with $\pm 5 \%$ with a detection limit of 2 ppbv. It was zeroed periodically by placing an ozone scrubber on the $1.5 \mathrm{~m}$ inlet and laboratory tests indicated no measurable loss of ozone within any of the PFA inlet lines.

2.5 Flux calculation using an Inverse Lagrangian Transport Scheme

Ecosystemscale fluxes of VOCs were calculated based on concentration gradients throughout the canopy and applying an Inverse Lagrangian Transport Model (Raupach, 1986; Nemitz et al., 2000; Karl et al., 2004).

The VOC fluxes were computed according to,

$$
\boldsymbol{C}-\mathrm{C}_{\mathrm{ref}}=\mathbf{D} \cdot \boldsymbol{S}
$$

where $C$ is the VOC concentration $\left(\mu \mathrm{g} / \mathrm{m}^{3}\right)$ vector for each level, $C_{\text {ref }}$ is the VOC concentration $\left(\mu \mathrm{g} / \mathrm{m}^{3}\right)$ at reference height (e.g. $14 \mathrm{~m}), \mathbf{D}(\mathrm{m})$ represents a dispersion matrix and $S$ $\left(\mathrm{mg} / \mathrm{m}^{2} / \mathrm{h} / \mathrm{m}\right)$ the resulting VOC source/sink vector. $\mathbf{D}$ can be expressed as a function of Lagrangian timescale (Tl) and profiles of the standard deviation of the vertical wind speed $\left(\sigma_{w}\right)$ divided by the friction velocity $\left(\mathrm{u}^{*}\right)$. The calculation was performed using a $10 \times 4$ dispersion matrix. Integration over all source and sink terms $(\boldsymbol{S})$ yields the canopy scale VOC flux $\left(\mathrm{mg} / \mathrm{m}^{2} / \mathrm{h}\right)$. Fluxes were calculated for $30 \mathrm{~min}$ intervals. The parameterization of $\mathbf{D}$ was based on turbulence measurements inside and above the canopy and calculated using the far- and near-field approach described by Raupach (1986). The Lagrangian timescale was parameterized according to Raupach (1986).
2.6 Canopy environment model estimates of leaf temperatures

Leaf temperatures of sun and shade leaves at each canopy depth were estimated using a canopy environment model (Guenther et al., 1995). This model calculates direct and diffuse, visible and near infrared solar radiation incident on sun and shade leaves at each canopy depth based on solar angle, above canopy solar radiation, canopy structure, and leaf characteristics. Wind speed, humidity and ambient temperature at each canopy depth are estimated using empirical functions. Leaf temperature is calculated using an energy balance approach that includes solar radiation, infrared radiation, convective heat flux, and latent heat flux terms. Daytime sun leaf temperature estimates can be several degrees warmer than ambient temperature due to increased solar radiation absorption, especially if water stress limits the ability of a leaf to cool by transpiration, while nighttime temperatures are several degrees cooler than ambient temperatures due to radiative losses of infrared energy.

\subsection{Measurement of Henry's Law Constants (HLC)}

HLC for Methylsalicylate (MeSA) and Methyljasmonate (MeJA) were measured using the single (Mackey et al., 1979) and double stripping cell configuration using PTRMS (Karl et al., 2003), where clean air (zero air) is introduced through a sintered glass disk into a stripping vessel, which contains distilled water and traces of MeSA and MeJA. On the way through the vessel the VOC reaches an equilibrium concentration in the air bubbles according to Henry's Law. Using a PTR-MS it can be shown that the HLC can be obtained from the declining countrate over time $(\operatorname{cps}(\mathrm{t}))$ plotted as a ratio to the initial initial countrate $\left(\mathrm{css}_{0}\right)$ according to:

$\ln \frac{\operatorname{cps}(\mathrm{t})}{\mathrm{cps}_{0}}=-\frac{\mathrm{F}}{\mathrm{HVRT}} \mathrm{t}$,

where $\mathrm{F}$ is the flowrate, $\mathrm{V}$ is the water volume, $\mathrm{R}$ is the ideal gas law constant, $\mathrm{T}$ is the temperature and $\mathrm{t}$ the time since start of the stripping experiment.

Here we obtain a HLC of $33.5 \pm 4.0 \mathrm{M} / \mathrm{atm}$ for MeSA and $5018 \pm 1003 \mathrm{M} / \mathrm{atm}$ for MeJA.

\section{Results}

We identified MeSA as a dominant reactive VOC constituent in ambient air based on mass spectral analysis using gaschromatographic pre-separation (GC-MS). Canopy air concentrations were also measured using an online ProtonTransfer-Reaction Mass Spectrometer (PTR-MS) (Lindinger et al., 1998). Figure 2a and b depict the vertical mixing ratio gradients of MeSA throughout the canopy observed in a walnut orchard during the Canopy Horizontal Array Turbulence Study (CHATS) obtained by PTR-MS. On JD 139 


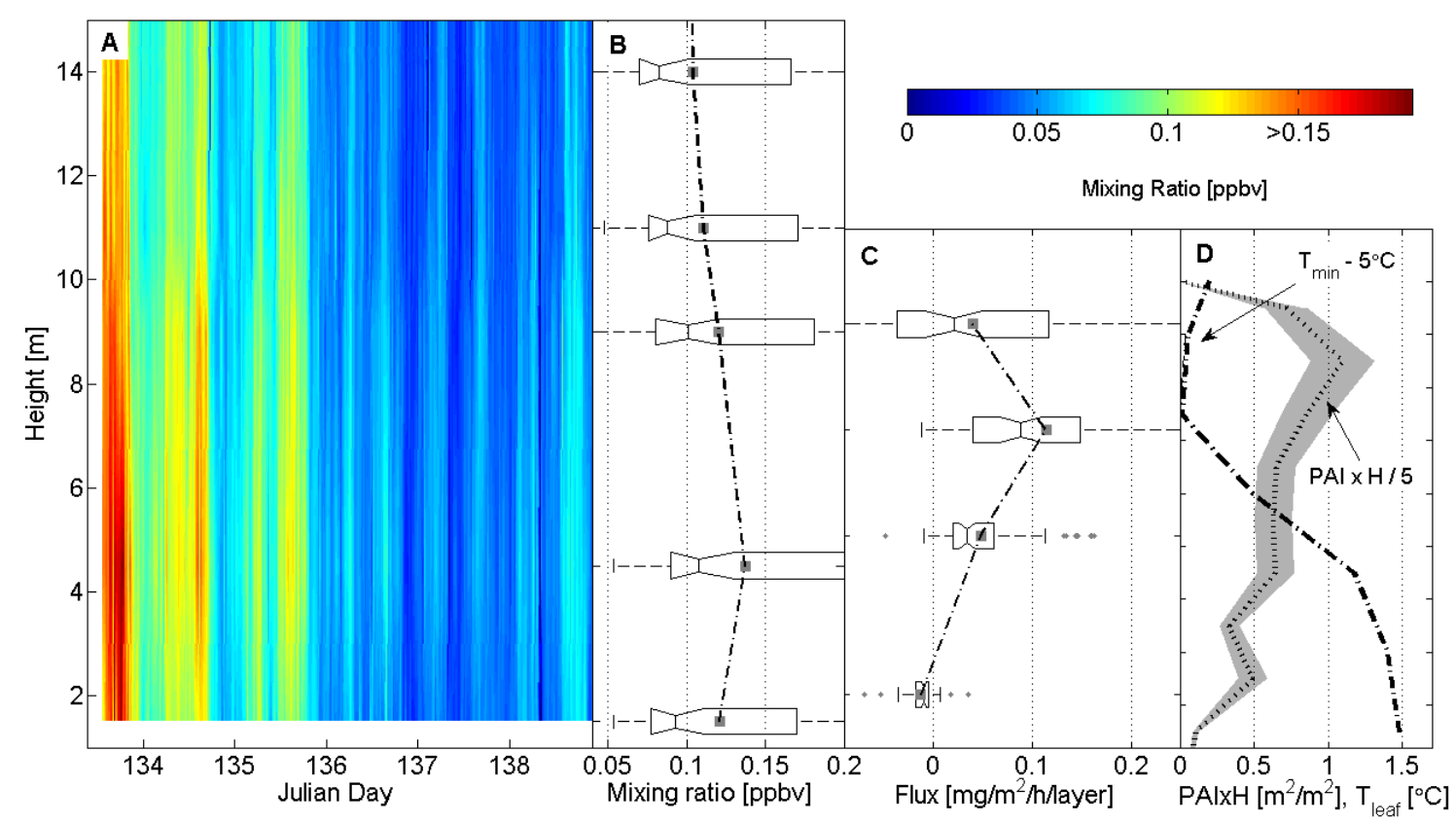

Fig. 2. (a) Vertical gradient of mixing ratios (colour coded). (b) Vertical gradient of daytime (10-18 local time) mixing ratios. Statistical box plot shows lower quartile, median and upper quartile (vertical lines of notched box), mean (gray squares connected with dashed line), whiskers (include $95 \%$ of data) and extreme values (gray dots). (c) Vertical flux gradient integrated over each flux layer and calculated for mixing ratio profiles shown in (a). (d) Vertical distribution of normalized plant area index $(\mathrm{PAI} \times \mathrm{H})$ and minimum night-time leaf temperatures $\left(\mathrm{T}_{\text {leaf }}\right.$ ) (an offset of $5^{\circ} \mathrm{C}$ was subtracted from $\mathrm{T}_{\text {leaf }}$ in order to plot both quantities on the same axis).

and 140 GC-MS samples were taken in ambient air at $3 \mathrm{~m}$ above ground. On JD 139 a direct intercomparison between GC-MS and PTR-MS mixing ratios demonstrated reasonable agreement (e.g. GC-MS: $19 \pm 5$ pptv; PTR-MS: $24 \pm 7$ pptv). A comparison between the two instruments measuring of a branch enclosure showed similar agreement (e.g. GC-MS: $400 \pm 60$ pptv; PTR-MS: $350 \pm 40$ pptv). We calculated the average daytime emission profile throughout the canopy for the period shown in Fig. 2a using an Inverse Lagrangian Transport (ILT) model (Fig. 2c). Peak emission rates occurred at the upper part of the canopy and coincided with the height at which night-time leaf temperatures reached a minimum (Fig. 2d). Figure 3 plots ambient air temperature, soil moisture (VWC), vapor pressure deficits (VPD) and the water stress factor (Ks) (Fig. 3a) along with MeSA and monoterpene (MT) mixing ratios (Fig. 3b), MT fluxes (Fig. 3c) and MeSA fluxes (Fig. 3d) observed during the study. Soil moisture was declining until JD146, when irrigation of the section of the plantation that was within the footprint of our measurements was started. The water stress factor Ks (a relative measure of water availability) was determined from soil moisture assuming a field capacity of 0.3 , a depletion factor of 0.5 and a permanent wilting point of 0.1 (Allen et al., FAO, 1998). When Ks equals zero a plant experiences the permanent wilting point. When Ks equals one water is readily available for the plant. Ks started dropping below one beginning on JD 136 and reached a minimum value of 0.4 before the irrigation system was initiated. After the irrigation cycle was started Ks generally remained above or close to 1 . It is noted that no rain events were recorded during the part of the study shown in Fig. 3. The highest emissions of MeSa were observed on Julian day (JD) $133\left(0.25 \mathrm{mg} / \mathrm{m}^{2} / \mathrm{h}\right)$ and declined thereafter. Corresponding average canopy mixing ratios were $250 \mathrm{pptv}$ on this day. The average MeSA flux over the entire study was comparable to the total MT flux (Fig. 4a) and therefore represented a major component of reactive biogenic VOC emissions in this agroforest. Daytime canopy-scale stomatal resistances (Rs) before irrigation calculated based on the Penman-Monteith equation exhibited average values of $214 \mathrm{~s} / \mathrm{m}$ with a median of $197 \mathrm{~s} / \mathrm{m}$. After the irrigation cycle was initiated (JD146) Rs decreased to a mean of $177 \mathrm{~s} / \mathrm{m}$ and a median of $162 \mathrm{~s} / \mathrm{m}$. The $\sim 20 \%$ lower Rs after irrigation was found to be statistically significant based on the Wilcoxon rank sum test (WRST) $(P=0.0017$, $n=911$ ). Similarly VPD was found to be $10 \%$ higher before irrigation (WRST: $P=6 \times 10^{-7}, n=911$ ) and was as high as $3.4 \mathrm{kPa}$ on JD133 (Fig. 3a). Systematically higher Rs and VPD before irrigation indicate that trees experienced the onset of drought stress to a point where they were forced to reduce water loss. This is also supported by low soil moisture resulting in a water stress factor between 0.4 and 1 before and close to 1 after irrigation.

Based on canopy scale MeSA concentrations (C), fluxes (F), stomatal conductance (gs) and measured HLC we can 


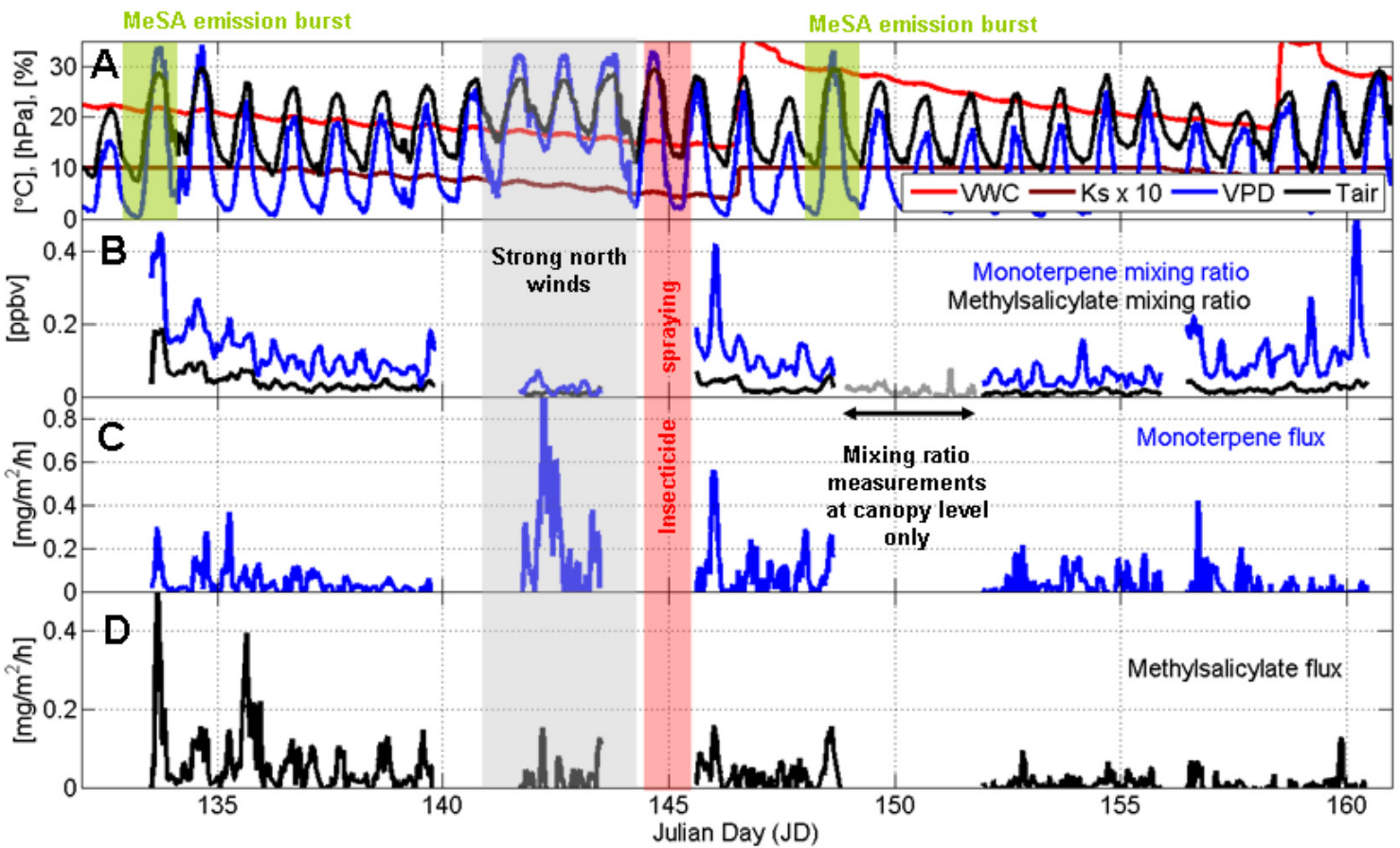

Fig. 3. (a) Air temperature (black), Vapor Pressure Deficit (VPD) (blue), soil moisture (as volumetric water content VWC) (red) and water stress factor (Ks) (dark red). (b) Mixing ratios of MT (blue) and MeSA (black) measured at $11 \mathrm{~m}$. Days when measurements of MeSA were performed at only one level are coloured gray. (c) Canopy scale integrated total MT flux. (d) Canopy scale integrated MeSA flux. Data collected between JD140 and JD144 were omitted from any analysis due to strong north winds resulting in a biased flux and concentration footprint.

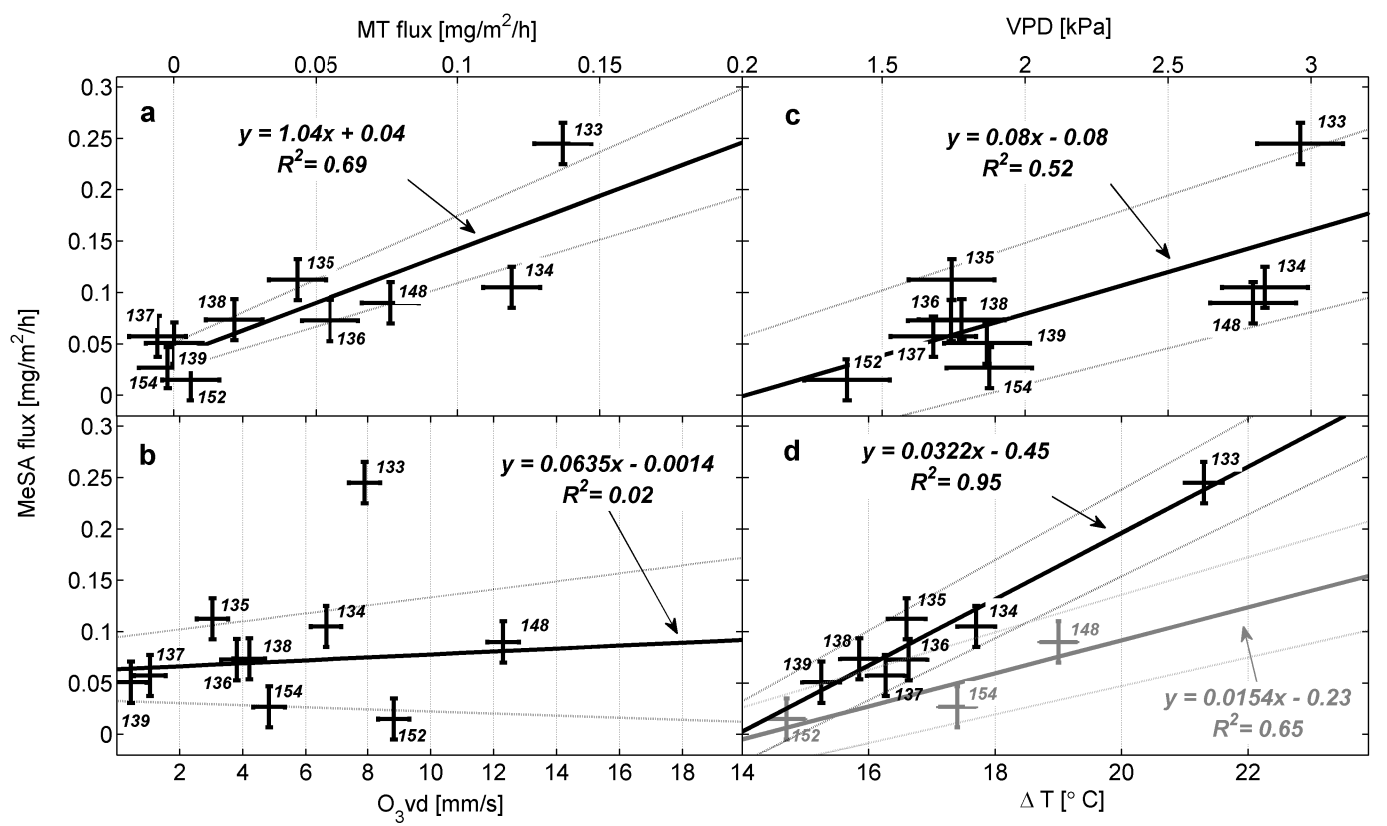

Fig. 4. (a), MeSA flux plotted vs MT flux. (b) MeSA flux plotted vs $\mathrm{O}_{3}$ deposition velocity (vd). (c) MeSA flux plotted vs VPD. (d) MeSA flux plotted versus $\Delta \mathrm{T}$ before irrigation (black) and after irrigation (gray). Data point labels indicate Julian Day. Fitting equation and $R^{2}$ are shown for each $\mathrm{x} / \mathrm{y}$ weighted fit. Dotted lines represent prediction bounds based on the standard deviation of the fitting parameters. 
calculate internal MeSA mixing ratios in leaves $\left(\mathrm{C}_{i}=(\mathrm{F} / \mathrm{gs}-\right.$ C); e.g. $C_{i}=7.8$ ppbv on JD 133), and, assuming most of it is dissolved in leaf water, estimate a range of liquid concentrations $\left(\mathrm{C}_{l}=\mathrm{HLC} \times \mathrm{C}_{i}\right.$; e.g. $\sim 40 \mu \mathrm{g} / \mathrm{l}$ on JD133 and $21 \mu \mathrm{g} / \mathrm{l}$ on JD148). For comparison a concentration range of $\sim 100$ $250 \mathrm{ng} / \mathrm{gFW}$ was reported by Park et al. (2006) in primary inoculated and uninoculated systemic mosaic tobacco leaves; their observations would correspond to a liquid concentration of $\sim 125-310 \mu \mathrm{g} / \mathrm{l}$ assuming that $80 \%$ of leaf fresh weight (FW) consisted of water. On JD143 and JD144 the leaves in the orchard were sprayed with an insecticide (DuPont, ASANA XL) for the only time during the experiment. In order to avoid contamination all chemical instrumentation had to be shut down. MeSA fluxes and mixing ratios were measured approximately $24 \mathrm{~h}$ (JD145) after the application of the insecticide. MeSA emissions after spraying were not statistically different at the 5\% significance level compared to days before the application of the insecticide (Two Sample T-Test: $\quad P($ before $=$ after $)=0.1495 ; \quad P($ before $>$ after $)=0.0748$, $n=32$ ). A number of biotic and abiotic stresses (e.g. herbivores/pathogens, ozone, temperature, drought) can induce the production of MeSA; during CHATS we can rule out the presence of a significant herbivore infestation due to a highly managed agroforest showing no sign of apparent physical leaf damage. With peak daytime ozone mixing ratios ranging between 39 and 70 ppbv during the study, plants did not experience acute exposure to ozone (e.g. study maximum (average) daily AOT40 ("accumulated dose over a threshold of 40 ppbv") $<130$ (60) ppbv h at VPD $>1.5 \mathrm{kPa}$ (Karlsson et al., 1998) and total study AOT40 $=1.2 \mathrm{ppm} \mathrm{h}$ (Fuhrer et al., 1997)). Consequently ozone mixing ratios did not exhibit a statistically significant correlation with MeSA emission rates $\left(R^{2}=0.24\right)$. Similarly no significant correlation $\left(R^{2}=0.02\right)$ between MeSA and ozone fluxes (Fig. 4b) was observed, suggesting that MeSA production was not primarily induced due to oxidative stress. The correlation between MeSA fluxes and VPD for the whole study exhibited an $R^{2}$ of 0.52 (Fig. 4c). Among all environmental and chemical data available during CHATS we found that the best predictor of MeSA fluxes was the difference between the minimum nighttime temperature of the previous night and the following maximum daytime temperature $(\Delta \mathrm{T})$. Figure $4 \mathrm{~d}$ shows a plot of mean daytime MeSA fluxes versus $\Delta \mathrm{T}$. The correlation between these quantities was statistically significant exhibiting an $R^{2}$ of 0.95 before irrigation and an $R^{2}$ of 0.65 after irrigation. For comparison correlations with maximum daytime temperatures (e.g. $R^{2}: 0.43$ ) or minimum temperatures of the previous night (e.g. $\left.R^{2}: 0.21\right)$ alone were rather poor. MeSA emissions were therefore likely a result of temperature stress possibly enhanced due to the onset of drought stress, which increases daytime leaf temperatures. Initial emission bursts typically followed a night with low temperatures that could induce chilling injury (Ding et al., 2002) (e.g. ambient temperature, $\mathrm{T}_{\text {ambient }}=7.5^{\circ} \mathrm{C}$, calculated minimum leaf-temperature, $\mathrm{T}_{\text {leaf, } \min }=4.6^{\circ} \mathrm{C}$ on JD133), and a subsequent temperature change of $\sim 20^{\circ} \mathrm{C}$ over the following day (e.g. $\Delta \mathrm{T}=21.3^{\circ} \mathrm{C}$ on JD133). A similar temperature change $\left(\Delta \mathrm{T}=19^{\circ} \mathrm{C}\right)$ occurred on JD148 after the irrigation schedule was started. The corresponding MeSA emission was clearly enhanced, but the average daytime canopy-scale flux was lower on JD148 than on JD133. These observations suggest that large temperature changes can trigger an ecosystem wide immune response; this is supported by the occurrence of lipid derived wound VOCs observed in PTRMS mass scans on JD133 and confirmed by GC-MS analyses indicating that 3-Z-hexenal was a dominant component. For example noontime mixing ratios (fluxes) of the sum of hexenal isomers were on the order of $1.5 \mathrm{ppbv}\left(0.8 \mathrm{mg} / \mathrm{m}^{2} / \mathrm{h}\right)$ on this day, declining to $0.3 \mathrm{ppbv}\left(0.1 \mathrm{mg} / \mathrm{m}^{2} / \mathrm{h}\right)$ over the following week. The correlation coefficient between $\mathrm{C}_{6}$ wound VOCs and MeSA noontime fluxes was 0.82. $\mathrm{C}_{6}$ wound VOCs such as 3-Z-hexenal are commonly observed when lipids are damaged and have been detected during mechanical wounding (Fall et al., 1999), herbivore infestations (Arimura et al., 2005), freezing (Fall et al., 2001) and drying (Karl et al., 2001) events, acute ozone exposure (Heiden et al., 1999) and after drastic changes of a plant's light environment (Graus et al., 2004). From Fig. 4d MeSA fluxes can be obtained as a function of $\Delta \mathrm{T}$. The pre-irrigation (JD133) and post-irrigation (JD148) emission events exhibited slopes of $0.032 \pm 0.004 \mathrm{mg} / \mathrm{m}^{2} / \mathrm{h} /{ }^{\circ} \mathrm{C}$ and $0.015 \pm 0.009 \mathrm{mg} / \mathrm{m}^{2} / \mathrm{h} /{ }^{\circ} \mathrm{C}$ respectively. MeSA emission pulses were thus a factor of $\sim 2$ lower after irrigation of the plantation started. Systematically higher daytime Rs and VPD before JD148 indicate that these differences could have been caused by a drought stressed ecosystem. Observations in this agroforest therefore support the idea that chilling injury at temperatures below $10-15^{\circ} \mathrm{C}$ can result in greater membrane damage at times when plants experience water deficit (Wright, 1974).

\section{Conclusions}

Our observations suggest that environmental factors can induce an ecosystem-wide immune response resulting in significant emissions of semivolatile plant hormones adding to the biogenic contribution of SOA. The atmospheric significance of plant hormones stems from their physiochemical properties. The vapor pressure of MeSA for example $\left(4.5 \mathrm{e}^{-5} \mathrm{~atm}\right)$ is two orders of magnitudes lower than that of commonly observed monoterpenes (e.g. alpha-pinene); the resulting saturation vapor pressure $\left(C^{*}=270 \mu \mathrm{g} / \mathrm{m}^{3}\right.$; $\mathrm{T}=25^{\circ} \mathrm{C}$ ) is in the range of carboxylic acids. For comparison $\mathrm{C}^{*}$ for Methyl jasmonate (MeJA) is $2.6 \mu \mathrm{g} / \mathrm{m}^{3}\left(\mathrm{~T}=25^{\circ} \mathrm{C}\right)$, close to values obtained for dicarboxylic acids. For typical ambient aerosol mass concentrations between $1-50 \mu \mathrm{g} / \mathrm{m}^{3}$ (Robinson et al., 2007), 0.4-18\% of MeSA could partition into the particle phase directly without prior oxidation in the atmosphere (Pankow, 1994). This fraction is likely a lower limit due to the neglect of gas-phase oxidation, which is 
expected to be fast with respect to reaction with the $\mathrm{OH}$ radical (e.g. $\mathrm{k}_{O H}=1.1 \mathrm{e}^{-11} \mathrm{~cm}^{3} / \mathrm{s}$ ). Plant hormones could therefore make an important contribution to biogenic secondary organic aerosol formation (Kanakidou et al., 2005) if concentrations and emission rates observed during this study are generalized to other ecosystems.

While a large body of literature on the defensive function of herbivore-induced VOCs inferred from laboratory experiments exists (Baldwin et al., 2006; Farmer, 2001), effects of environmental parameters on plant-specific constitutive responses, in particular, the relationship between abiotic and biological stresses have not been studied systematically in the field. Whether higher production rates of MeSA (and SA) during periods of moderate water limitation could help stressed plants to deal with imminent pathogen or herbivore infestations more successfully under field conditions merits further investigation in the future. Ecosystem-scale measurements of MeSA within emerging ecological networks (e.g. the National Ecological Observatory Network - NEON (http://www.neoninc.org/)) could potentially play an important role in improving our understanding of plant health under naturally occurring conditions.

Acknowledgements. The authors thank the entire ISFF team of the Earth Observing Laboratory (NCAR) for their excellent project management, logistical support, and help during CHATS. We would also like to express our sincere gratitude to both the Cilker family and to A. Paredes for allowing the CHATS campaign to take place on their property, and to J. Grant of the University of California Cooperative Extension in Stockton, CA, who helped us find Cilker Orchards. The National Center for Atmospheric Research is operated by the University Corporation for Atmospheric Research under sponsorship from the National Science Foundation.

Edited by: A. Arneth

\section{References}

Allen, R. G., Pereira, L. S., Raes, D., and Smith, M.: Crop evapotranspiration - Guidelines for computing crop water requirements - FAO Irrigation and drainage paper, Food and Agriculture Organization of the United Nations, Rome, 56, ISBN 92-5104219-5, 1998.

Arimura, G., Kost, C., and Boland, W.: Herbivore-induced, indirect plant defences, Biochim. Biophys. Acta, 1734, 91-111, 2005.

Atkinson, R.: Atmospheric chemistry of VOCs and NOx, Atmos. Environ., 34, 2063-2101, 2000.

Baldwin, I. T., Halitschke, R., Paschold, A., von Dahl, C. C., and Preston, C.: Volatile signaling in plant-plant interactions: "Talking trees" in the genomics era, Science, 311, 812-815, 2006.

Beckers, G. J. M. and Spoel, S. H.: Fine-Tuning Plant Defence Signalling: Salicylate versus Jasmonate, Plant Biology, 8, 1-10, 2006.

Di Carlo, P. D., Brune, W. H., Martinez, M., Harder, H., Lesher, R., Ren, X., Thornberry, T., Carroll, M. A., Young, V., Shepson, P. B., Riemer, D., Apel, E., and Campbell, C.: Missing OH reactivity in a forest: Evidence for unknown reactive biogenic VOCs, Science, 304, 722-725, 2004.
Ding, C. K., Wang, C. Y., Gross, K. C. and Smith, D. L.: Jasmonate and salicylate induce the expression of pathogenesisrelated-protein genes and increase resistance to chilling injury in tomato fruit, Planta, 214, 895-901, 2002.

Fall, R., Karl, T., Hansel, A., Jordan, A., and Lindinger, W.: Volatile organic compounds emitted after leaf wounding: On-line analysis by proton-transfer-reaction mass spectrometry, J. Geophys. Res.-Atmos., 104, 15 963-15 974, 1999.

Fall, R., Karl, T., Jordan, A., and Lindinger, W.: Biogenic C5VOCs: release from leaves after freeze-thaw wounding and occurrence in air at a high mountain observatory, Atmos. Environ., 35, 3905 3916, 2001.

Farmer, E. E.: Surface-to-air signals, Nature, 411, 854-856, 2001.

Fuhrer, J., Skärby, L., and Ashmore, N. M.: New Directions: Use and abuse of the AOT40 concept, Environ. Pollut., 97, 11571158, 1997.

Goldstein, A. and Galbally, I. E.: Known and unexplored organic constituents in the earth's atmosphere, Environ. Sci. Technol., 41, 1514-1521, 2007.

Graus, M., Schnitzler, J. P., Hansel, A., Cojocariu, C., Rennenberg, H., Wisthaler, A., and Kreuzwieser, J.: Transient release of oxygenated volatile organic compounds during light-dark transitions in grey poplar leaves, Plant Physiol., 135, 196-1975, 2004.

Guenther, A., Hewitt, C. N., Erickson, D., Fall, R., Geron, C., Graedel, T., Harley, P., Klinger, L., Lerdau, M., Mckai, W. A., Pierce, T., Scholes, B., Steinbrecher, R., Tallamraju, R., Taylor, J., and Zimmerman, P.: A global model of natural volatile organic compound emissions, J. Geophys. Res.-Atmos., 100, 8873-8892, 1995.

Hansel, A., Jordan, A., Warneke, C., Holzinger, R., Wisthaler, A., and Lindinger, W.: Proton-transfer-reaction mass spectrometry (PTR-MS): on-line monitoring of volatile organic compounds at volume mixing ratios of a few pptv, Plasma Sources Sci. T., 8, 332-336, 1999.

Heiden, A.C., Hoffmann, T., Kahl, J., Kley, D., Klockow, D., Langebartels, C., Mehlhorn, H., Sandermann, H., Schraudner, M., Schuh, G., and Wildt, J.: Emission of volatile organic compounds from ozone-exposed plants, Ecol. Appl., 9, 1160-1167, 1999.

Kanakidou, M., Seinfeld, J. H., Pandis, S. N., Barnes, I., Dentener, F. J., Facchini, M. C., Van Dingenen, R., Ervens, B., Nenes, A., Nielsen, C. J., Swietlicki, E., Putaud, J. P., Balkanski, Y., Fuzzi, S., Horth, J., Moortgat, G. K., Winterhalter, R., Myhre, C. E. L., Tsigaridis, K., Vignati, E., Stephanou, E. G., and Wilson, J.: Organic aerosol and global climate modelling: a review, Atmos. Chem. Phys., 5, 1053-1123, 2005, http://www.atmos-chem-phys.net/5/1053/2005/.

Karl, T., Potosnak, M., Guenther, A., Clark, D., Walker, J., Herrick, J.D., and Geron, C.: Exchange processes of volatile organic compounds above a tropical rain forest: Implications for modeling tropospheric chemistry above dense vegetation, J. Geophys Research, 109, D18306, doi:10.1029/2004JD004738, 2004.

Karl, T., Yeretzian, C., Jordan, A., and Lindinger, W.: Dynamic measurements of partition coefficients using proton-transferreaction mass spectrometry (PTR-MS), Int. J. Mass Spectrom., 223, 383-395, 2003. 
Karl, T., Guenther, A., Lindinger, C., Jordan, A., Fall, R., and Lindinger, W., Eddy covariance measurements of oxygenated volatile organic compound fluxes from crop harvesting using a redesigned proton-transfer-reaction mass spectrometer, J. Geophys. Res.-Atmos., 106, 24 157-24 167, 2001.

Karlsson, G. P., Karlsson, P. E., Soja, G., Vandermeiren, K., and Pleijel, H.: Test of the short-term critical levels for acute ozone injury on plants - improvements by ozone uptake modelling and the use of an effect threshold, Atmos. Environ., 38, 2237-2245, 1998.

Kesselmeier, J. and Staudt, M.: Biogenic volatile organic compounds (VOC): An overview on emission, physiology and ecology, J. Atmos. Chem., 33, 23-88, 1999.

Li, X., Schuler, M., and Berenbaum, M. R.: Jasmonate and salicylate induce expression of herbivore cytochrome $\mathrm{P} 450$ genes, Nature, 419, 712-715, 2002.

Lindinger, W., Hansel, A., and Jordan, A.: Proton-transfer-reaction mass spectrometry (PTR-MS): on-line monitoring of volatile organic compounds at pptv levels, Chem. Soc. Rev., 27, 347-354, 1998.

Mackay, D., Shiu, W. Y, and Sutherland, R. P.: Determination of air water Henry's Law Constants for hydrophobic pollutants, Environ. Sci. Technol., 13, 333-337, 1979.

Nemitz, E., Sutton, M. A., Gut, A., Jose, R. S., Husted, S., and Schjoerring, J. K.: Sources and sinks of ammonia within an oilseed rape canopy, Agr. Forest Meteorol., 105, 385-404, 2000.
Pankow, J. F. : An absorption model of the gas aerosol partitioning involved in the formation of secondary organic aerosol, Atmos. Environ., 28, 189-193, 1994.

Park, S. W., Kaimoyo, E., Kumar, D., Mosher, S., and Klessig, D. F.: Methyl salicylate is a critical mobile signal for plant systemic acquired resistance, Science, 318, 113-116, 2006.

Peñuelas, J., Lluisà, J., and Filella, I.: Methyl salicylate fumigation increases monoterpene emission rates, Biol. Plantarum, 51, 372376, 2006.

Raupach, M. R.: A practical Lagrangian method for relating scalar concentrations to source distributions in vegetation canopies, Q. J. Roy. Meteor. Soc., 115, 609-632, 1989.

Robinson, A., Donahue, N. M., Shrivastava, M. K., Weitkamp, E. A., Sage, A. M., Grieshop, A. P., Lane, T. E., Pierce, J. R., and Pandis, S. N.: Rethinking organic aerosols: Semivolatile emissions and photochemical aging, Science, 315, 1259-1262, 2007.

Shulaev, V., Silverman, P., and Raskin, I.: Airborne signalling by methyl salicylate in plant pathogen resistance, Nature, 385, 718721, 1997.

Wright, M.: Effect of chilling on ethylene production, membrane permeability and water loss of leaves of phaseolus vulgaris, Planta, 120, 63-69, 1974. 